\title{
Food preference and comparative feeding efficacy of Chrysoperla carnea (Stephens) in population management of invasive Cotton mealybug, Phenacoccus solenopsis (Tinsley)
}

\author{
Bhugro Mal ${ }^{1}$, Hakim Ali Sahito ${ }^{2 *}$, Abdul Hafeez Mastoi ${ }^{3}$, Shoib Rahim ${ }^{4}$, \\ Attaullah Khan Pathan ${ }^{1}$, Wali Muhammad Mangrio ${ }^{2}$ and Tasneem \\ Kousar $^{2}$ \\ 1. PARC-Southern Zone Agricultural Research Centre, Karachi, (75270), Sindh, Pakistan \\ 2. Department of Zoology, Shah Abdul Latif University, Khairpur (66111), Sindh, Pakistan \\ 3. Department of Entomology, Lasbella University of Agriculture, Water and Marine Sciences, Uthal (80700), \\ Balochistan, Pakistan \\ 4. Department of Agriculture and Agribusiness, University of Karachi (75270), Sindh, Pakistan \\ *Corresponding author's email: hakim.sahito@salu.edu.pk
}

\section{Citation}

Bhugro Mal, Hakim Ali Sahito, Abdul Hafeez Mastoi, Shoib Rahim, Attaullah Khan Pathan, Wali Muhammad Mangrio and Tasneem Kousar. Food preference and comparative feeding efficacy of Chrysoperla carnea (Stephens) in population management of invasive Cotton mealybug, Phenacoccus solenopsis (Tinsley). Pure and Applied Biology. Vol. 11, Issue 2, pp651-660. http://dx.doi.org/10.19045/bspab.2022.110066

\begin{tabular}{llll}
\hline \hline Received: 25/06/2021 & Revised: 28/08/2021 & Accepted: 07/09/2021 & Online First: 18/09/2021 \\
\hline \hline
\end{tabular}

\section{Abstract}

The knowledge of preference and feeding efficacy of a predator plays an important role in visualizing its role in pest management programs. The present research study was conducted to have a deep insight into the predatory potential and preference of Chrysoperla carnea on different instars of $P$. solenopsis, which was performed in the Bio-control Laboratory at PARCSARC, Karachi. The cotton mealybugs were collected from the okra crop and further multiplied on potatoes sprouts at $\left(26 \pm 2^{\circ} \mathrm{C}\right.$ and $\left.65 \pm 5 \% \mathrm{RH}\right)$ for feeding the larvae of $C$. carnea and all larval stages expressed response when they fed over the different instars of $P$. solenopsis. Predatory performance increased with the advancement in the growth of the larval stage as the maximum performance was expressed by the third-stage larva of $C$. carnea. The successive instars $\left(1^{\text {st }}\right.$ to $\left.3^{\text {rd }}\right)$ consumed per day on an average $(50.89 \pm 0.51),(92 \pm 0.33)$, and $(144.67 \pm 0.66)$ on first instars of $P$. solenopsis. Each larval stage took three days to enter into the next phase. A single larva right hatching from an egg to prepupal stage consumed an average of 866.67 first instars of cotton mealybug. All larval instars preferred first instars of $P$. solenopsis and exhibited less preference towards the second and third stages. The first stage larva did not at all consume the third instar of $P$. solenopsis. The findings of the present study suggested that; $C$. carnea is a very 
successful predator of $P$. solenopsis, easy to rear in the laboratory, and can be exploited for the biological control of cotton mealybug under field conditions.

Keywords: Biological control; Chrysoperla carnea; Cotton mealybug; Feeding efficacy; IPM

\section{Introduction}

The Cotton mealybug, Phenococcus solenopsis (Tinsely) is a polyphagous invasive insect pest in Sindh, Pakistan has been recorded from more than 154 different species of plants including; cotton, okra, tomato, eggplant, sesame, sunflower, and ornamentals and it has also been found infesting different types of weeds as well [1] has been recorded from 35 different ecological zones of the world [2]. As a result of the sucking of sap, the growth of cotton plants is stunted, leaves turn yellow, and affected plants produce a lesser number of bolls [3]. The cotton mealybugs, in addition to sucking the sap from plants also excrete honeydew which serves as a medium for the development of sooty mold, which interferes with the process of photosynthesis and also reduces the market value of lint [4]. Ants also feed on honeydew secreted by mealybugs and play an important role in their spread and also deter natural enemies from playing their role [5]. Under favorable climatic conditions population of $P$. solenopsis is greatly increased and natural enemies available in the crop do not bring to below ETL, levels in the crop. Hence, chemical interventions become necessary to protect the crop from the ravages of pests. In this scenario, the development of the IPM package is necessary to reduce the pressure of pesticides [6]. The farmers mainly depend upon synthetic chemical pesticides for controlling insect pests in their crops; however, $P$. solenopsis due to the development of waxy secretions on its body is difficult to control with chemical pesticides [7]. Environment and biodiversity are also affected due to the intensive use of synthetic pesticides used for controlling various insect pests in crops [8]. The concept of pest management suggested by [9] suggests the use of both biological and chemical control methods for pest control in agricultural systems. The growers seek alternatives to synthetic chemical pesticides for controlling different insect pests in their crops. Given this their interest in using natural enemies as an alternative to chemical pesticides has recently increased. The main component of the IMP is biological control and pest control can be effectively achieved utilizing biological control [10]. The mealybug infestations on different host plants can also be effectively brought under control using natural enemies [11].

Among the generalist predators that are available for controlling different insect pests, the Chrysoperla carnea is a very important one and can be effectively exploited for controlling different insect pests in IPM programs [12, 13, 14]. This predator is frequently found in cotton crops [15], Okra [16], and Oilseeds [17]. It has a wide host range like whiteflies, thrips, mealybugs, aphids, neonate lepidopterous larvae, and eggs of different arthropods. Larvae of this predator express cannibalism when there is a shortage of host/food. Female of this predator laid several hundred small eggs with stalks on the underside of leaves and small shoots during dark hours. Eggs of this predator hatch in three to six days and the larvae that emerge from eggs eat voraciously on their prey and molt three times $[18,19,20]$. This predator has high searching efficiency [21] and also has developed high resistance capability against many pesticides that are massively used for the control of a variety of pest insects [22]. The money spent on the import of pesticides can be reduced by utilizing this predator in pest management programs [23]. Nowadays, this predator is commonly reared in 
biological control laboratories and is extensively used for biological control of different insect pests of agricultural importance throughout the world [24]. This predator has huge potential to be commercialized and for integration in IPM programs for the management of a variety of insect pests in different crops [25, 26, 27]. In Pakistan, this predator has been used for the management of cotton mealybugs and proved to be an efficient predator of cotton mealybugs [28]. Because of the importance of this predator in the management of cotton mealybug, this study was undertaken to know its preference, and consumption potential was confirmed on the different instars of cotton mealybug under laboratory conditions.

\section{Materials and Methods Study area}

The studies on food preference and comparative feeding efficacy of different laboratory-reared and field captured larva of Chrysoperla carnea (Stephens) (Neuroptera: Chrysopidae) on different stages of cotton mealybug, Phenococcus solenopsis (Tinsely) were undertaken in the biological control laboratory of Pest Management Research Institute, PARC, SARC, at $26 \pm 2^{\circ} \mathrm{C}$

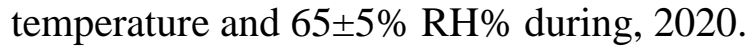

\section{Rearing of Phenococcus solenopsis} (Hemiptera: Pseudococcidae)

Cotton mealybugs were collected from the okra crop and further multiplied on sprouted potatoes. The potatoes with small buds were purchased from the market, brought in the laboratory, washed and dried, and put under soaked gunny bags for sprouting. The gunny bags were slightly sprinkled with water daily to maintain moisture for the quick sprouting of potatoes. The potatoes took 10-15 days to sprout. The cotton mealybugs were released on these sprouted potatoes for further multiplication. The cotton mealybugs multiplied freely on these potatoes and colony established for feeding to $C$. carnea larvae.

Rearing of Chrysoperla carnea (Stephens) (Neuroptera: Chrysopidae)

Chrysoperla carnea larvae were collected from okra crop grown at the SARC-PARC, Karachi from Experimental field brought under the laboratory and released on sprouted potatoes on which cotton mealybugs had been established. The potatoes were put in rectangular cages, made of a $6 \mathrm{~cm}$ thick, transparent plastic sheet. When larvae of $C$. carnea turned into adults, the adults were provided with an artificial diet in the ratio of $70 \mathrm{ml}$ distilled water, one tablespoon honey, one tablespoon sugar, and a $5.5 \mathrm{~g}$ yeast solution. The artificial diet was discarded after two days and a new one was prepared. The food was provided on the sides of cadges in drops and also in a plastic strip with closed round holes. The soaked cotton swab was also placed in cadges for fulfilling the water requirement of adults of green lacewing. The food was provided on daily basis. A black granulated paper underside the removable top of the cage was provided for oviposition purposes of Chrysoperla carnea. Eggs were harvested with a razor every morning and placed in $9 \mathrm{~cm}$ diameter Petri dishes for hatching. The eggs took three to four days to hatch. The larvae hatched from eggs were put separately in Petri dishes to avoid the possibility of cannibalism due to voracious feeding in nature. The moistened filter papers were put in the base of Petri dishes to provide optimum conditions for the suitable growth of larva.

Consumption potential of predator to pest In a bid to check the consumption potential of $1^{\text {st }}$ to $3^{\text {rd }}$ laboratory-reared, as well as field-collected stages of Chrysoperla carnea on first to third cotton mealybug instars and the different larvae stages of $C$. carnea were separately released into 9c.m diameter Petri dishes and given a definite number of 
specific instars of $P$. solenopsis in three replications. The specific instars of cotton mealybugs were separated with the help of camel hairbrushes from the general population and released into Petri dishes. To avoid the escape of mealybugs, the Petri dishes were covered with lids. The fresh okra leaves were placed in Petri dishes for feeding cotton mealybugs. Daily consumption of each stage of Chrysoperla carnea on each instar of $P$. solenopsis was examined by subtracting the daily number of consumed from the total number of mealybugs that were released into the Petri dishes. The counting of numbers of $P$. solenopsis consumed by each larval stage was carried out every 24 hours until the larva entered the next phase (Fig. 1).

Statistical analysis

The differences in total consumption between $1^{\text {st }}, 2^{\text {nd }}$, and $3^{\text {rd }}$ instar of $C$. carnea on different stage instars of $P$. solenopsis were calculated by analysis of variance using the statistical software (SXW 8.1 USA). Further confirmation means were separated through the least significance test at a $5 \%$ significance level.

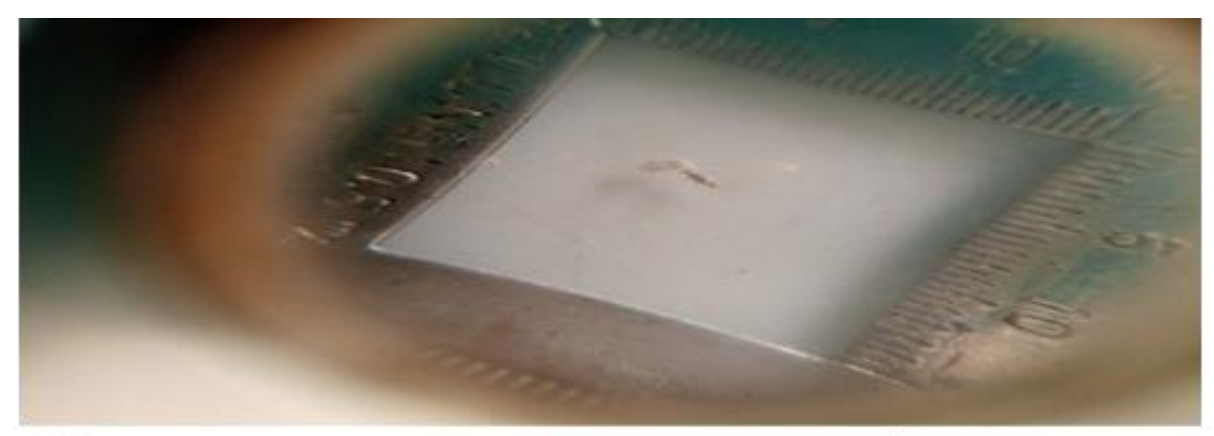

$1^{\text {st }}$ instar of $P$. solenopsis being consumed by the $1^{\text {st }}$ stage of $C$. carnea

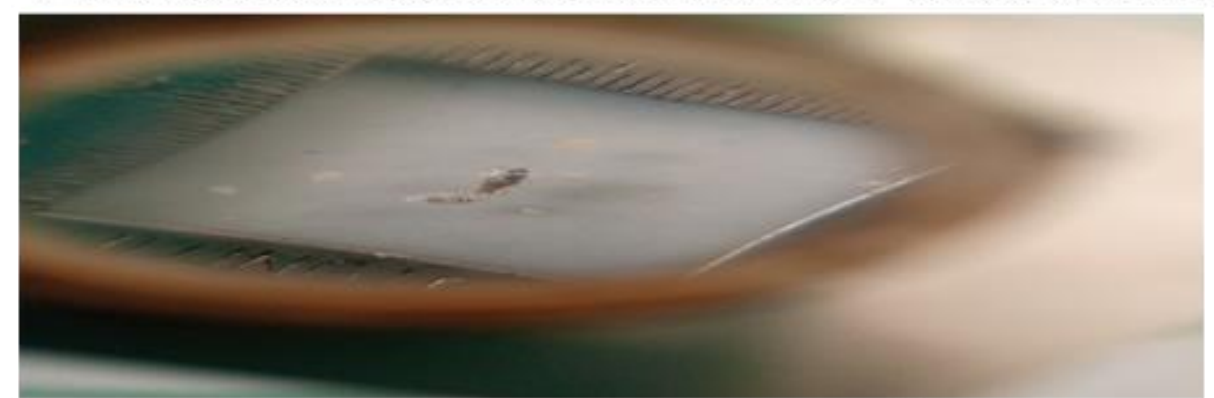

$1^{\text {st }}$ instar of $P$. solenopsis being consumed by the $2^{\text {nd }}$ stage of $C$. carnea

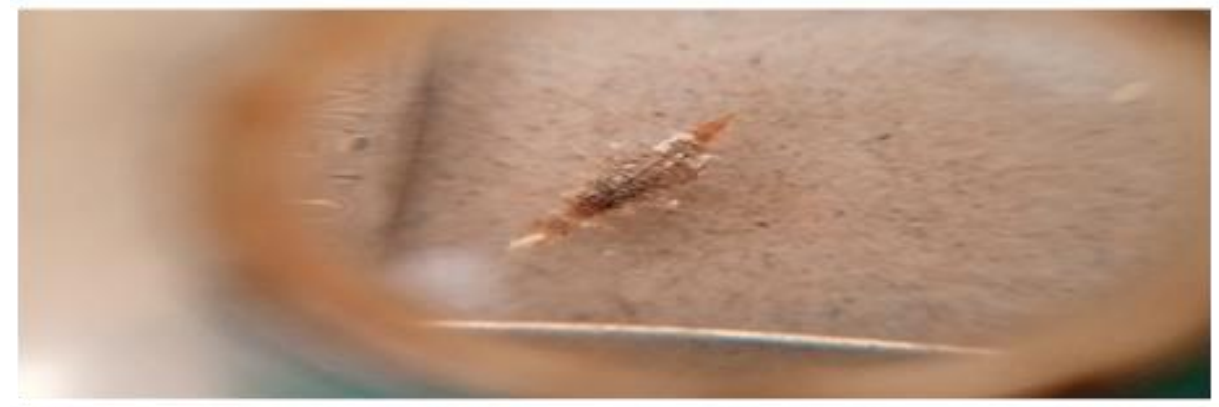

$1^{\text {st }}$ instar of $P$. solenopsis being consumed by the $3^{\text {rd }}$ stage of $C$. carnea

Figure 1. Food preference and comparative feeding efficacy of $C$. carnea in population management of $\boldsymbol{P}$. solenopsis under laboratory conditions 


\section{Results \\ The consumption rate of laboratory- reared larva}

The results of the present findings revealed that all larval instars of $C$. carnea expressed performance against the different stages of $P$. solenopsis. However, the $1^{\text {st }}$ instars of $P$. solenopsis frequently preferred mostly all larval instars of $C$. carnea. The consumption strength of $C$. carnea larva significantly increased with its stage advancement. The $1^{\text {st }}$ larval stages of $C$. carnea consumed on an average $(152.67 \pm 1.56)$ first instar, (3.66 \pm 0.143$)$ second instar, and (0) third instar $P$. solenopsis respectively in three days period. The second stage of $C$. carnea extremely used the double number of different $P$. solenopsis stages compared with the $1^{\text {st }}$ star and consumed on an average (276 \pm 2.67$)$ first instar, (7.32 \pm 1.78$)$ second instar, and $(0.99 \pm 0.89)$ third instar $P$. solenopsis in three days period respectively. The third instars were found to be a voracious feeder and consumed almost triple the more number of different stages of $P$. solenopsis than the first stage of $C$. carnea and consumed $(437.01 \pm 1.66)$ first instars, (12.66 \pm 1.36$)$ second instars, and (5.34 \pm 0.71$)$ third instar of $P$. solenopsis, respectively in three days period before entering into prepupal stage (Table 1). Each instar took three days to enter into the next phase.

A single larva right from emerging from the egg up to entering into prepupal stage consumed on an average 866.67 first instar $P$. solenopsis. The mean per day consumption of successive larval instars of C. carnea on the $1^{\text {st }}$ instars of $P$. solenopsis was $\quad(50.89 \pm 0.51), \quad(92 \pm 0.33), \quad$ and (145.67 \pm 0.66$)$, respectively and significantly different from each other $(\mathrm{DF}=2,8$; $\mathrm{F}=1852.394 ; \mathrm{P}=0.000)$. All larval instars of C. carnea exhibited less preference towards the second instars $P$. solenopsis as compared to first instar cotton mealybugs. The mean per day consumption of successive larval stages of $C$. carnea on the second instar $P$. solenopsis was $(1.22 \pm 0.192),(2.44 \pm 0.192)$, and $(4.22 \pm 0.19)$ respectively and significantly different from each $(\mathrm{DF}=2,8$; $\mathrm{F}=93.3 ; \mathrm{P}=0.000$ ). All larval instars expressed extreme non-preference towards the third instar $P$. solenopsis and nonpreference might be due to its bigger size and presence of waxy secretions on its body. The first instar did not at all fed on the third instar $P$. solenopsis due to its smaller size in comparison with it. The second instar consumed worth nothing and the third instar hardly consumed $1.78 \pm 0.51$ third instar $P$. solenopsis per day. The mean per day consumption of successive larval stages of Chrysoperla carnea on third instars of $P$. solenopsis was $(00),(0.33 \pm 0.192)$, and $(1.78 \pm 0.51)$, respectively and significantly different from each other $(\mathrm{DF}=2,8 ; \mathrm{F}=41.8$; $\mathrm{P}=$ 0.0003). However, significant differences in feeding rate between $1^{\text {st }}$ instars and $3^{\text {rd }}$ instars and non-significant differences between $2^{\text {nd }}$ and $3^{\text {rd }}$ larval instars of $C$. carnea on $3^{\text {rd }}$ instar of $P$. solenopsis were observed when means were compared through the least significance test (LSD) as shown in (Table 2).

\section{The consumption rate of field captured Chrysoperla carnea larvae}

The results of mean consumption rate of successive field captured larval stages of Chrysoperla carnea on successive instars of $P$. solenopsis were almost the same as those of laboratory-reared Chrysoperla carnea larva. The mean consumption rate of successive field-collected larval instars of $C$. carnea on first instars of $P$. solenopsis per day was (43.78 \pm 0.69$),((92.56 \pm 0.1 .64)$ and (144.33 \pm 0.33$)$, respectively and significantly different from each other $(\mathrm{DF}=2,8$; $\mathrm{F}=15.500 ; \mathrm{P}=0.004)$. As such, the mean consumption rate of successive field captured larval instars of $C$. carnea on second instars of $P$. solenopsis per day was 
$(1.44 \pm 0.19), \quad(2.33 \pm \quad 0) \quad(4.11 \pm 0.69)$ respectively and significantly different from each other $(\mathrm{DF}=2,8 ; \mathrm{F}=15.500 ; \mathrm{P}=0.004)$. The field captured first instar larvae of $C$. carnea also did not feed on third instars of P.solenopsis. The mean consumption rate of successive field captured larva of $C$. carnea on third instars of $P$. solenopsis per day recorded was $(00), \quad(0.33 \pm 0.192)$ and (1.44 \pm 0.19$)$, respectively and significantly different from each other ( $\mathrm{DF}=2,8 ; \mathrm{F}=41.8$; $\mathrm{P}=0.0003$ ). However, the (LSD) test at a $5 \%$ significance level found nonsignificance differences in consumption rate between the first and second stages of $C$. carnea on the third instars of $P$. solenopsis further justification is given in (Table 3 ).

Relative Comparison of consumption rate b/w laboratory-reared and field captured Chrysoperla carnea larva on $P$. solenopsis The first stage of predator provided the 100 first stage, 200 to the second stage and 300 to the third stage of pest to both kinds of laboratory-reared and field captured organisms from which, the lab-reared consumed (145.67 \pm 0.66$)$ and field captured $(144.33 \pm 0.33)$ with the highest pest consumption by the predator were observed under laboratory conditions. The significant differences $(\mathrm{DF}=5,17 ; \mathrm{F}=2083 ; \mathrm{P}=0.000)$ in the consumption of mean rate between different stages of $C$. carnea larva on first instars of $P$. solenopsis were observed. However, non-significant differences between the same categories of $C$. Carnea except the first instar on the first instars of $P$. solenopsis were observed when means were subjected through the least significance test. In the same way, significant differences between different categories $(\mathrm{DF}=5,17$; $\mathrm{F}=57.6 ; \quad \mathrm{P}=0.000)$ and non-significant differences between the same categories on second instar mealybugs were observed when means were compared through the least significance test. Same results were obtained $(\mathrm{DF}=5,17 ; \mathrm{F}=34 ; \mathrm{P}=0.000)$ on third instar $P$. solenopsis (Table 4).

Table 1. Three days mean consumption of different laboratory-reared larval instars of $C$. carnea on different instars of $P$. solenopsis

\begin{tabular}{|c|c|c|c|}
\hline \multirow{2}{*}{ Chrysoperla carnea (stages) } & \multicolumn{3}{|c|}{ P. solenopsis (instars) } \\
\cline { 2 - 4 } & First & Second & Third \\
\hline First & $152.67 \pm 1.56^{\mathrm{c}}$ & $3.66 \pm 1.43^{\mathrm{c}}$ & $0.00 \pm 0.00^{\mathrm{b}}$ \\
\hline Second & $276.00 \pm 02.67^{\mathrm{b}}$ & $7.32 \pm 1.78^{\mathrm{b}}$ & $0.99 \pm 0.89^{\mathrm{b}}$ \\
\hline Third & $437.01 \pm 1.66^{\mathrm{a}}$ & $12.66 \pm 1.36^{\mathrm{a}}$ & $5.34 \pm 0.71^{\mathrm{a}}$ \\
\hline
\end{tabular}

Means followed by the similar letters in columns are significantly different $(\mathrm{P}<0.05)$ using the LSD test

Table 2. Per day mean consumption of different laboratory-reared larval instars of $C$. carnea on different instars of $P$. solenopsis

\begin{tabular}{|c|c|c|c|}
\hline \multirow{2}{*}{ Chrysoperla carnea (stages) } & \multicolumn{3}{|c|}{ P. solenopsis (instars) } \\
\cline { 2 - 4 } & First & Second & Third \\
\hline First & $50.89 \pm 0.51^{\mathrm{c}}$ & $1.22 \pm 0.192^{\mathrm{c}}$ & $0.00 \pm 0.00^{\mathrm{b}}$ \\
\hline Second & $92.00 \pm 0.33^{\mathrm{b}}$ & $2.44 \pm 0.192^{\mathrm{b}}$ & $0.33 \pm 0.192^{\mathrm{b}}$ \\
\hline Third & $145.67 \pm 0.66^{\mathrm{a}}$ & $4.22 \pm 0.19^{\mathrm{a}}$ & $1.78 \pm 0.51^{\mathrm{a}}$ \\
\hline
\end{tabular}

Means followed by similar letters in columns are significantly different $(\mathrm{P}<0.05)$ using the LSD test 
Table 3. Per-day mean consumption different field captured larval instar of $C$. carnea on different instars of $P$. solenopsis

\begin{tabular}{|c|c|c|c|}
\hline \multirow{2}{*}{ Chrysoperla carnea (stages) } & \multicolumn{3}{|c|}{ P. solenopsis (instars) } \\
\cline { 2 - 4 } & First & Second & Third \\
\hline First & $43.78 \pm 0.69^{\mathrm{c}}$ & $1.44 \pm 0.19^{\mathrm{c}}$ & $0.00 \pm 0.00^{\mathrm{b}}$ \\
\hline Second & $92.56 \pm 1.64^{\mathrm{b}}$ & $2.33 \pm 0.0^{\mathrm{b}}$ & $0.33 \pm 0.92^{\mathrm{b}}$ \\
\hline Third & $144.33 \pm 0.33^{\mathrm{a}}$ & $4.11 \pm 0.69^{\mathrm{a}}$ & $1.44 \pm 0.19^{\mathrm{a}}$ \\
\hline
\end{tabular}

Means followed by similar letters in columns are significantly different $(\mathrm{P}<0.05)$ using the LSD test

Table 4. Relative per day comparison between consumption potential of laboratory-reared and field captured larva of $C$. carnea on $P$. solenopsis

\begin{tabular}{|c|c|c|c|c|c|c|}
\hline \multirow{2}{*}{$\begin{array}{c}\text { P. solenopsis } \\
\text { (instars) }\end{array}$} & $\begin{array}{c}\text { Cab-reared } \\
1^{\text {st }} \text { stage }\end{array}$ & $\begin{array}{c}\text { Field- } \\
\text { captured } \\
1^{\text {st }} \text { stage }\end{array}$ & $\begin{array}{c}\text { Lab- reared } \\
2^{\text {nd }} \text { stage }\end{array}$ & $\begin{array}{c}\text { Field } \\
\text { captured } \\
2^{\text {nd }} \text { stage }\end{array}$ & $\begin{array}{c}\text { Lab-reared } \\
3^{\text {rd }} \text { stage }\end{array}$ & $\begin{array}{c}\text { Field } \\
\text { captured } \\
3^{\text {rd }} \text { stage }\end{array}$ \\
\hline First & $50.89 \pm 0.51^{\mathrm{c}}$ & $43.78 \pm 0.69^{\mathrm{d}}$ & $92.33 \pm 0.33^{\mathrm{b}}$ & $92.56 \pm 1.64^{\mathrm{b}}$ & $145.67 \pm 0.66^{\mathrm{a}}$ & $144.33 \pm 0.33^{\mathrm{a}}$ \\
\hline Second & $1.22 \pm 0.192^{\mathrm{c}}$ & $1.44 \pm 0.19^{\mathrm{c}}$ & $2.44 \pm 0.19^{\mathrm{b}}$ & $2.33 \pm 0.00^{\mathrm{b}}$ & $4.22 \pm 0.19^{\mathrm{a}}$ & $4.11 \pm 0.69^{\mathrm{a}}$ \\
\hline Third & 0.00 & 0.00 & $0.33 \pm 0.192^{\mathrm{b}}$ & $0.33 \pm .192^{\mathrm{b}}$ & $1.78 \pm 0.51^{\mathrm{a}}$ & $1.44 \pm 0.19^{\mathrm{a}}$ \\
\hline
\end{tabular}

Means followed by similar letters in columns are significantly different $(\mathrm{P}<0.05)$ using the LSD test

\section{Discussion}

The results of this research study show that all $C$. carnea larval stages prey upon the different stages of instars of $P$. solenopsis and predatory performance of lava significantly increased with the advancement in the stage of larva and reached its maximum in the third stage. The various researchers like [29-33], have also documented the predatory performance of $C$. carnea increased with the advancement in the stages of larva, and the third larval stage consumed the maximum number of sucking pest species when used as prey. [34] their research findings also reported the $3^{\text {rd }}$ larval stages of $C$. carnea consumed different nymph stages and the maximum number of $P$. solenopsis nymphs in comparison with the $1^{\text {st }}$ and $2^{\text {nd }}$ instar due to its increased nutritional requirements and bigger. In our research findings, all larval stages of Chrysoperla carnea expressed maximum preference towards $1^{\text {st }}$ instar of cotton mealybug and consumed its maximum numbers in comparison with the $2^{\text {nd }}$ and $3^{\text {rd }}$ instar of $P$. solenopsis due to mobile in nature. On the first instar of $P$. solenopsis the significant differences were observed in the consumption rate between the successive instars. The results of our research study are similar to the findings of [35], who documented significant differences in the rate of consumption between different larval stages of $C$. carnea on first instars of $P$. solenopsis. [34, 36] reported that different stages of Chrysoperla carnea preferred first instars of $P$. solenopsis to second and third instar.

The reason for the choice of $1^{\text {st }}$ instar $P$. solenopsis by all larval stages of Chrysoperla carnea might be due to its smaller size and absence of waxy coating on its body and also its high mobility compared to the $2^{\text {nd }}$ and $3^{\text {rd }}$ instar whereas, $C$. carnea prefer to prey on fast-moving insects compared to slow ones [12]. Our findings are also in conformity with the hypothesis that predators mostly choose the stages of a host which could maximize their fitness for successful prey. Because of this the best control of $P$. solenopsis via this predator it would be better to release $C$. carnea in fields when cotton mealybug is in its first or second stage. The large-sized prey can be 
overcome and weaken the predator species and may result in a reducing predator population, i-e., in coccinellid beetles that fed on soft-bodied insect species, their consumption rate ultimately decreased as their prey size increased. In anthocorid beetles, the consumption rate on prey also declined with the increase in the size of prey [37]. Thus; [38] observed the different insecticides against cotton mealybug as their effect on the natural enemies and [39] found residual impact under laboratory conditions [40] observed the varietal resistance of this invasive cotton mealybug pest. The results of the present research study showed nonsignificant differences in the rate of consumption between the same categories of laboratory-reared and field captured larval stages of $C$. carnea on the same stages of $P$. solenopsis (except first instar). The significant difference in consumption rate between laboratory-reared larvae and field captured first instar larva of $C$. carnea of the first instar $P$. solenopsis might be distance problematic since field captured first-stage larvae of $C$. carnea that have disturbed due to its smaller size while handling and bringing it from field to laboratory conditions.

\section{Conclusion and Recommendations}

The main motto of the present research study was to explore the food preference and predatory potential of $C$. carnea on $P$. solenopsis as a natural balancing ecosystem. The results of the research study revealed that Chrysoperla carnea under laboratory conditions can be easily massreared on cotton mealybug and best utilized for the efficient biological control of $P$. solenopsis in the IPM program. However, our research findings revealed that the third stage of $P$. solenopsis is least preferred by all the instars of $C$. carnea. Therefore, it is recommended that Chrysoperla carnea should be released in the field when $P$. solenopsis is in its first or second stage.

\section{Authors contributions}

The experiment designated and conceived: Bhugro M, Experiments performed: Shoib R, Kousar T, Data analyzed: HA Sahito, Contributed tools, materials, analyses: Pathan AK \& Mastoi AH, Wrote the paper: Bhugro M \& WM Mangrio.

\section{Acknowledgment}

The authors are highly thankful to Pest Management Research Institute, PARC, SARC, Karachi for providing biological control laboratory for research work and manuscript write-up.

\section{References}

1. Afzal M, Rahman SU \& Siddiqui MT (2009). Appearance and management of a new devastating pest of cotton, Phenacoccus solenopsis (Tinsley) in Pakistan. Belt wide Cotton Conference San Antonio Texas pp 5-8.

2. Culik MP \& Gullan PJ (2005). A new pest of tomato and other records of mealybugs (Hemiptera: Pseudococcidae) from Espirito Santo, Brazil. Zootaxa 964: 1-8.

3. Dhawan AK, Sing J, \& Sidhu AS (1980). Maconellicoccus sp. attacking Gossypium arboreum cotton in Punjab. J Sci Culture 46(7): 258.

4. Saeed S, Ahmad M \& Kwon YJ (2007). Insecticidal control of the mealybug Phenacoccus gossypiphilous (Hemiptera: Pseudococcidae). Entomol Res 37: 76-80.

5. Cudjoe AR, Neuenschwander $P$ \& Copland MJW (1993). Interference by ants in biological control of Cassava mealybug, Phenococcus manihoti (Homoptera; Seudococcidae) in Ghana. Bull Entomol Res 83: 15-22.

6. Van den Bosch R, Messenger PS \& Gutierrez AP (1982). An introduction to biological control. Plenum Press.

7. Joshi MD, Butani PG, Patel VN \& Jeyakumar P (2010). Cotton mealybug, Phenacoccus solenopsis. Agric Rev 31: 113119.

8. Bellows TS, (2001). Restoring population balance through natural enemy introductions. Biol Cont 21: 199205. 
9. Stern VM, Smith RF, Van den Bosch R, \& Hagen KS (1959). The integrated control concept. Hilgardia 29: 81-101.

10. Pedigo JP \& Rice ME (2010). Entomology and pest management. Prentice-Hall of India PVT. Ltd. New Dehli 1100.

11. Mohyuddin AI, Jilani G, Khan AG, Humza AI \& Mehmood Z (1997). Integrated pest management of major cotton pests by conservation, redistribution, and augmentation of natural enemies. Pak J Zool 29(3): 293-298.

12. Huang N \& Enkegaard A (2009). Predation capacity and prey preference of Chrysoperla carnea on Pierisbrassicae. J Biol Control 55: 379-385.

13. Bozsik A, Ramon GR \& Baltasar H (2009). Distribution of the Chrysoperla carnea complex in Southern Spain (Neuroptera: Chrysopidae). In: International Symposia Risk Factors for Environment and Food Safety \& Natural Resources and Sustainable Development, Faculty of Environmental Protection, November 6-7 Spain pp: 71-78.

14. Memon AS, Omar D, Muhamad DR, Sajap AS, Asib N \& Gilal AA (2015). Functional responses of green lacewing, Chrysoperla nipponensis (Neuroptera: Chrysopidae) reared on natural herb-based artificial diet. J Entoml and Zoo Stu 3(6): 80-83.

15. Mallah GH, Korejo AK, Soomro AR \& Soomro AW (2001). Population dynamics of predatory insects and biological control of cotton pests in Pakistan. J Bi ol Sci 1: 245-248.

16. Saeed R, Razaq M \& Hardy ICW (2015). The importance of alternative host plants as reservoirs of the cotton leafhopper, Amrasca devastans, and its natural enemies. J Pest Sci 88: 517-531.

17. Aslam M, \& Razaq M (2007). Arthropod fauna of Brassica napus and Brassica juncea from Southern Punjab (Pakistan). $J$ Agric Urb Ent 24: 49-50.

18. Hagle EAC \& Miles N (1987). Release of Chrysoperla carnea Stephens (Neuropteran: Chrysopidae) for control of
Tetranychusurticae Koch on peach grown in a protected environment structure. The Canadian Entomol 119: 205-206.

19. Carrillo M \& Elanov P (2004). The potential of Chrysoperla carnea as a biological control agent of Myzus persicae in glass houses. Annals of Appl Biol 32: 433-439.

20. Venkatesan S, Balasubramani G, Babu PCS \& Sivaram (1997). Use of nuclear polyhedrosis virus and green lacewing, Chrysoperla carnea Stephens for Helicoverpa armigera (Hubner) management on sunflower. Pest Manage and Eco Zool 5: 63-66.

21. Ridgway RL \& Murphey WL (1984). Biological control in the field. In Canard, M. Semeria, Y and New, TR (eds.), Biology of Chrysopidae. Junk Boston pp. 220-227.

22. Bigler F (1984). Biological control by chrysopids. Integration with pesticides, In Carnrd, M., Semeria, Y., and New, R.T. [eds.], Biology of Chrysopids. Junk Boston pp. 233-245.

23. Zia K, Khuram Z, Hafeez F, Rashid R, Arshad M \& Naeem Ullah U (2008). Effectiveness of Chrysoperla carnea (Stephens) (Neuroptera: Chrysopidae) on the Population of Bemisia tabaci (Homoptera: Aleyrodidae) in Different Cotton Genotypes. J Agri and Social sciences 4(3): 112-116.

24. Tauber M.J, Tauber CA, Daane KM \& Hagen KS (2000). Commercialization of predators: recent lessons from green lacewings (Neuroptera: Chrysopidae: Chrysoperla). Am J Entomol 46: 26-38.

25. Atakan E (2000). Within plant distribution of predators Chrysoperla carnea, Deraeocorispallens and Oriusniger in cotton. Turk J Entomol 4: 267-277.

26. Sengonca C, Griesbach M \& Lochte C (1995). Suitable predator-prey ratios for the use of Chrysoperla carnea (Stephens) eggs against aphids on sugar beet under laboratory and field conditions. $A n z$ Schardlingsk Pflaanzensch 102: 113-120. 
27. Legaspi JC, Nordlund DA \& Legaspi BC (1996). Tritrophic interactions and predation rates in Chrysoperla spp. attacking the silver leaf whitefly. South Western J Entomol 21: 3342.

28. Sattar M, Hameed M \& Nadeem S (2007). The predatory potential of Chrysoperla carnea (Stephens) (Neuroptera: Chrysopidae) against the cotton mealybug. Pak Entomologist 29: 103-106.

29. Krishnamoorthy A \& Mani M (1982). Feeding potential and development of Chrysopa scelestes Banks on Heliothis armigera (Hubn.) under laboratory conditions. Entomol 7: 385-388.

30. Megahed M, Abou-Zeid NA, Farghaly HT, Marei SS \& Zeid NAA (1984). The predating efficiency of Chrysopa carnea Steph. on certain hosts. Agric Res Rev 60: 201- 208.

31. Jagadish KS \& Jayaramaiah M (2004). Biology and predatory potentiality of Chrysoperla carnea on the tobacco aphid, Myzus nicotine (Homoptera). J Ecobiol 16: 161-167.

32. Rabinder K, Kaur R \& Brar KS (2008). Development and predation efficacy of Chrysoperla carnea (Stephens) on mealybug, Phenococcus solenopsis (Tinsley) under laboratory conditions. J Insect Sci 21: 93-95.

33. Saminathan VR, Mahadevan NR \& Muthukrishnan N (2003). Influence of prey density on the predatory potential and development of Chrysoperla carnea. Indian J Entomol 65: 1- 6.

34. Gautam RD \& Tesfaye A (2002). Potential of green lacewing, Chrysoperla carnea
(Stephens) in crop pest management. New Agric 13: 147-58.

35. Azhar H, Sayyed H, Akram W, Raza S \& Ali M (2012). The predatory potential of Chrysoperla carnea and Cryptolaemus montrouzieri larvae on different stages of the mealybug, Phenacoccus solenopsis: A threat to cotton in South Asia. J Ins Sci 12:1-12.

36. Hameed A, Saleem M, Ahmad S, Aziz MI \& Karar H (2013). Influence of prey consumption on life parameters and predatory potential of Chrysoperla carnea against cotton mealybug. Pak J Zool 45(1): 177182.

37. Dixon AFG \& Russel RJ (1972). The effectiveness of Anthocoris nemorum and A. confusus (Heteroptera: Anthocoridae) as a predator of Sycamore aphid. Drepanosiphum platanoidis. Searching behavior and the incidence of predation in the field. Entomol Experi Et Appl 15: 3550.

38. Sahito HA, Abro GH, Syed TS, Lanjar AG \& Khajjak AS (2011). Screening of pesticides against cotton mealybug, Phenacoccus solenopsis Tinsley and its natural enemies on cotton crop. Intern Res J Bioch and Bioinfo 1(9): 232-236.

39. Kousar T, Sahito HA, Jatoi FA, Shah ZH \& Mangrio WM (2016). Resistant insecticides of cotton mealybug, Phenacoccus solenopsis (Tinsley) under laboratory conditions. $J$ Ento and Zool Stu 4(6): 355-359.

40. Sahito HA, Abro GH, Khuhro RD \& Buriro AS (2009). Varietal resistance of cotton crop against mealybug, Phenacoccus solenopsis Tinsley. Pak J Agric, Agri Engg Vet Sci 25(1): 34-38. 